\title{
Investigation of the Effect of Inclusive Play and Special Movement Education to Social Communication in Disadvantaged and Peer Children in Preschool (Erzurum Sample)
}

\author{
Sertaç Erciş (Corresponding author) \\ Department of Recreation, Faculty of Sports Sciences, Atatürk University, Erzurum, Turkey \\ E-mail: sertac@atauni.edu.tr
}

\begin{abstract}
Ahmet Şirinkan
Department of Recreation, Faculty of Sports Sciences, Atatürk University, Erzurum, Turkey E-mail: asirinkan@atauni.edu.tr
\end{abstract}

\section{Levent Önal}

Department of Recreation, Faculty of Sports Sciences, Atatürk University, Erzurum, Turkey E-mail: levent.onal@atauni.edu.tr

Received: November 5, $2021 \quad$ Accepted: December 6, 2021

Published: December 31, 2021

doi:10.5296/jei.v7i3.19155 URL: https://doi.org/10.5296/jei.v7i3.19155

\begin{abstract}
The aim of this research is to investigate the effect of inclusive play and special movement education applied to disadvantaged and peer preschool children in Erzurum city center on their basic skills.

22 students (10 disadvantaged children +12 peer group children) consisting of disadvantaged children and peer children who were educated in special education and rehabilitation centers in the city center of Erzurum and participated voluntarily. Before the study, two seminars were given to the parents of the students, which determined the purpose and objective of the research. Students participated in a specially prepared game and movement training program
\end{abstract}


for 45-60 minutes, 2 days a week during the summer period. Before starting the research, an interview and observation form consisting of 10 questions was prepared for the parents of the children and the results were recorded. At the end of the 2-month (8-week) period, interviews and observations were made with the parents of the children, and the last situation was recorded and compared with the previous situation.

In the first parent interviews, the results of the research; it was observed that the children hesitated to participate in the study, they do not want to get close to other children, refrain from sharing game materials and avoid playing together and do not help. While they stated that they did not comply with the game discipline, they stated that at the end of the study program, their initial negative behavior developed completely in a positive way. In expert observations; it was observed that at the beginning, the children did not want to participate in the studies, did not listen to the volunteers, acted randomly, fought over the play materials used, and avoided playing together. While they observed that they behaved randomly, it was stated that the observations developed completely positively at the end of the research process.

As a result, it was concluded that inclusive play and special movement training applied to disadvantaged preschool children and peers contributed positively to the social development of children.

Keywords: Pre-school, Game, Movement education, Social communication

\section{Introduction}

In the Special Education Regulation in Turkey, enacted in 2000, inclusive education is defined as "formal and private education of individuals in need of special education, together with their peers who do not have disabilities, by providing support education services; pre-school, primary education, secondary education, and non-formal education institutions are defined as special education practices based on their continuation" (Republic of Turkey Ministry of National Education, 2000). It is not enough to support inclusion practices only by laws. In order for this application to be carried out fully and correctly, some factors must also be taken into account. These factors include teachers, school personnel, parents, inclusive students, regular class students, physical arrangements and individualized education programs, school management and senior administrators. In inclusive practices, especially children's teachers have an important role in adapting children to each other and to the programs. This may also play a role in the success of the inclusion study. Inclusion in the pre-school period, which is one of the most critical periods of life, is of great importance in terms of acquiring the basic communication skills necessary for facilitating the adaptation of the disabled child to society in the following years and accelerating their development (Gampel, Galtlieb, \& Harrison, 1974; Metin, 1992).

The pre-school education period is known as the critical years for the development of the child. With the inclusion programs to be implemented in this period, children with special needs have the opportunity to experience the gains they have gained among their peers, and they can take other children as a model with the friendships and they will establish 
(Shickedanz, 1994). Teachers, who have an important role in the success of inclusion; it is a powerful mediator in terms of both the social atmosphere and behavior of the classroom. In the integration of students with disabilities into the classroom students with normal development in all classroom conditions (Dönmez, Avc1, \& Aslan, 1997).

Children with special needs have different mental, social and emotional characteristics from their normally developing peers. Therefore, special models are used in the education of children with special needs. Along with the changes in the field of education, the model of integrating children with normal development and children who need special education has become widespread (Sucuoğlu \& Özokçu, 2005). The number of children with special needs is increasing day by day and they leave their isolated educational environments and receive education in pre-school education institutions together with their peers (MEB, 2010). Inclusive education is the training of classroom teachers and/or experts in general education classes for students with special needs, provided that special education services are provided (Kircaali \& İftar, 1992). In the preschool period, the place where a child can communicate intensely with $\mathrm{s} /$ he own motivation is seen as leisure activities. It has been observed that children interact more in free play activities than in work-based activities (Leseman et al., 2001). In the free time period, children can find the opportunity to play with the materials in the learning center they want. The situations where communication is most intense are naturally social games. Because social games contain opportunities where a child can show and learn social communication behaviors in accordance with his/her own level of development. Children make eye contact with each other, play together, guide the in-game developments with their offers, learn to adapt to the flow of the game, and most importantly, they are in constant social communication (Kohler \& Strain, 1993).

A child with special needs needs to observe, model and communicate with normally developing peers. Behaviors of both normally developing and children with special needs in accordance with social norms and their communication with each other increase with social games. Social games are games that are usually played in groups (Parten, 1933). Children in the playing group are influenced by each other and adapt to each other. Children use the elements and relationships they remember from real life experiences in their communication within the game. Thus, while children learn to cope with their negative impulses, they have a happy feeling with play. It may be sufficient for the child to have a friend to play group games. However, the game must take place by mutual participation and communications must be of the same purpose or due to the requirements of the purpose (Rubin, 1989). Communication skills expected from children are not just to give clear messages or to put what they want to say into words correctly. Interpretation skills, comprehension skills, and appropriate use of facial and body language are expected (Arslan, Erbay, \& Saygin, 2010).

When we look at mutual communication, factors such as the individual's attitudes, abilities, social roles, self-concept, perceptions of the other person, and the level of knowledge about the subject are important factors in the initiation and ongoing process of communication (Cüceloğlu, 1997). Personal characteristics of individuals determine the form and frequency of communication (Burgoon, Berger, \& Waldron, 2000). When we consider a kindergarten with inclusion students, how disadvantaged children are perceived by their peers and how 
they perceive their peers affects their social communication. However, inadequacies in social communication cause a great decline in social and academic skills (Zirpoli \& Melloy, 1997). Therefore, knowing the social games and social communication features of children with special needs with their peers is necessary for the successful execution of the inclusion program.

\section{Method}

22 students (10 disadvantaged children +12 peer group children) consisting of disadvantaged children and peer children who were educated in special education and rehabilitation centers in the city center of Erzurum and participated voluntarily. Before the study, two seminars were given to the parents of the students, which determined the purpose and objective of the research. Students participated in a specially prepared game and movement training program for 45-60 minutes, 2 days a week during the summer period. Before starting the research, an interview and observation form consisting of 10 questions was prepared for the parents of the children and the results were recorded. At the end of the 2-month (8-week) period, interviews and observations were made with the parents of the children, and the last situation was recorded and compared with the previous situation. The IQ levels of children with special needs were included in the study with permission from the Guidance and Research Center reports.

\section{Result}

Table 1. Age, height, weight and IQ status of the students participating in the research

\begin{tabular}{|l|l|l|l|l|l|l|l|l|l|l|l|}
\hline Age & $\mathbf{N}$ & $\mathbf{\%}$ & Height & $\mathbf{N}$ & $\mathbf{\%}$ & Weight & $\mathbf{N}$ & $\%$ & $\mathbf{I Q}$ & $\mathbf{N}$ & $\%$ \\
\hline 3 & 1 & 5.5 & $123-125$ & 1 & 5.5 & $39-42$ & 1 & 5.5 & $50-70$ & 1 & 5.5 \\
\hline 4 & 4 & 10.5 & $137-139$ & 3 & 10.5 & $40-43$ & 4 & 10.5 & $50-70$ & 3 & 10.5 \\
\hline 5 & 4 & 10.5 & $135-137$ & 4 & 10.5 & $45-48$ & 4 & 10.5 & $45-60$ & 4 & 10.5 \\
\hline 4 & 2 & 10.5 & $145-147$ & 2 & 10.5 & $46-49$ & 2 & 10.5 & $45-60$ & 2 & 10.5 \\
\hline 5 & 3 & 15 & $152-154$ & 3 & 15 & $52-55$ & 3 & 15 & Normal & 3 & 15 \\
\hline 4 & 3 & 15 & $158-160$ & 3 & 15 & $55-59$ & 3 & 15 & Normal & 3 & 15 \\
\hline 3 & 2 & 10.5 & $157-159$ & 2 & 10.5 & $58-61$ & 2 & 10.5 & Normal & 2 & 10.5 \\
\hline 4 & 2 & 10.5 & $160-162$ & 3 & 10.5 & $60-63$ & 2 & 10.5 & Normal & 3 & 10.5 \\
\hline 5 & 1 & 5.5 & $162-164$ & 1 & 5.5 & $63-65$ & 1 & 5.5 & Normal & 1 & 5.5 \\
\hline
\end{tabular}

When Table 1 is examined, 12 students participating in the research are stated as partner students and 10 students as students in need of special education. 
Table 2. Special Movement Education Program Applied in the Research

\begin{tabular}{|c|c|c|}
\hline Aim & ontents & Gains \\
\hline Walking, running, jumping. & $\begin{array}{l}\text { Straight walking, slalom walking, straight } \\
\text { running, slalom running, standing jumping, } \\
\text { walking jumping. }\end{array}$ & $\begin{array}{l}\text { Being able to walk, run and jump with } \\
\text { balance. }\end{array}$ \\
\hline $\begin{array}{l}\text { Holding, } \\
\text { throwing. }\end{array}$ & $\begin{array}{l}\text { Ball holding, ball throwing, tennis ball } \\
\text { holding, grasping and throwing, soft ball } \\
\text { grasping and throwing. }\end{array}$ & $\begin{array}{l}\text { To be able to hold, grasp and throw objects } \\
\text { correctly and firmly. }\end{array}$ \\
\hline $\begin{array}{l}\text { Lie down and roll over, } \\
\text { body rotation. }\end{array}$ & $\begin{array}{l}\text { Lying and rolling on the gym mat, turning } \\
\text { the body in different directions. }\end{array}$ & $\begin{array}{l}\text { Ability to move, rotate and roll the body on } \\
\text { the ground. }\end{array}$ \\
\hline Walking, running, jumping. & $\begin{array}{l}\text { Straight walking, slalom walking, straight } \\
\text { running, slalom running, standing jumping, } \\
\text { walking jumping. }\end{array}$ & $\begin{array}{l}\text { Being able to walk, run and jump with } \\
\text { balance. }\end{array}$ \\
\hline $\begin{array}{l}\text { Holding, } \\
\text { throwing. }\end{array}$ & $\begin{array}{l}\text { Ball holding, ball throwing, tennis ball } \\
\text { holding, grasping and throwing, soft ball } \\
\text { grasping and throwing. }\end{array}$ & $\begin{array}{l}\text { To be able to hold, grasp and throw objects } \\
\text { correctly and firmly. }\end{array}$ \\
\hline $\begin{array}{l}\text { Lie down and roll over, } \\
\text { body rotation. }\end{array}$ & $\begin{array}{l}\text { ing and rolling on the gym mat, turning } \\
\text { body in different directions. }\end{array}$ & ody on \\
\hline $\begin{array}{l}\text { Hand-holding and throwing, } \\
\text { foot-holding and hitting, } \\
\text { targeting. }\end{array}$ & $\begin{array}{l}\text { Catching and re-throwing the thrown ball, } \\
\text { catching and hitting the rolled ball with the } \\
\text { foot, throwing the ball to the target with the } \\
\text { hands and feet. }\end{array}$ & $\begin{array}{l}\text { To be able to hold, control and throw balls } \\
\text { of different sizes and weights. }\end{array}$ \\
\hline $\begin{array}{l}\text { alls at the target } \\
\text { and feet. }\end{array}$ & $\begin{array}{l}\text { Kicking soft ball to target, kicking tennis } \\
\text { all to target, Kicking soccer ball to target. }\end{array}$ & $\begin{array}{l}\text { control and throw balls } \\
\text { d weights. }\end{array}$ \\
\hline Moving on the gym mat. & d somersault roll & $\begin{array}{l}\text { To be able to hold, control and throw balls } \\
\text { of different sizes and weights. }\end{array}$ \\
\hline $\begin{array}{l}\text { Hand-holding and throwing, } \\
\text { foot-holding and hitting, } \\
\text { targeting. }\end{array}$ & $\begin{array}{l}\text { Catching and re-throwing the thrown ball, } \\
\text { catching and hitting the rolled ball with the } \\
\text { foot, throwing the ball to the target with the } \\
\text { hands and feet. }\end{array}$ & $\begin{array}{l}\text { To be able to hold, control and throw balls } \\
\text { of different sizes and weights. }\end{array}$ \\
\hline $\begin{array}{l}\text { balls at the target } \\
\text { ds and feet. }\end{array}$ & $\begin{array}{l}\text { cking soft ball to target, kicking tennis } \\
11 \text { to target, Kicking soccer ball to target. }\end{array}$ & ad throw balls \\
\hline Mov & Forward somers & $\begin{array}{l}\text { To be able to hold, control and throw balls } \\
\text { of different sizes and weights. }\end{array}$ \\
\hline $\begin{array}{l}\text { Rolling, climbing, } \\
\text { balancing, bouncing. }\end{array}$ & $\begin{array}{l}\text { at mat, climbing on a high } \\
\text { aring gymnastics, single leg } \\
\text { louble leg ricochet. }\end{array}$ & $\begin{array}{l}\text { To be able to roll, climb, walk in balance, } \\
\text { bounce in a balanced and smooth manner. }\end{array}$ \\
\hline $\begin{array}{l}\text { Rolling, climbing, } \\
\text { balancing, bouncing. }\end{array}$ & $\begin{array}{l}\text { Rolling on a flat mat, climbing on a high } \\
\text { mat, walking during gymnastics, single leg } \\
\text { on rope ladder, double leg ricochet. }\end{array}$ & $\begin{array}{l}\text { To be able to roll, climb, walk in balance, } \\
\text { bounce in a balanced and smooth manner. }\end{array}$ \\
\hline $\begin{array}{l}\text { Climbing, gripping and } \\
\text { swinging }\end{array}$ & $\begin{array}{l}\text { Climbing the bars, holding on to the } \\
\text { pull-ups and swinging in the ring. }\end{array}$ & $\begin{array}{l}\text { Climb the gymn } \\
\text { to the pull-up ba }\end{array}$ \\
\hline $\begin{array}{l}\text { Rolling, climbing, } \\
\text { balancing, bouncing. }\end{array}$ & $\begin{array}{l}\text { Rolling on a flat mat, climbing on a high } \\
\text { mat, walking during gymnastics, single leg } \\
\text { on rope ladder, double leg ricochet. }\end{array}$ & $\begin{array}{l}\text { To be able to roll, climb, walk in balance, } \\
\text { bounce in a balanced and smooth manner. }\end{array}$ \\
\hline $\begin{array}{l}\text { Rolling, climbing, } \\
\text { balancing, bouncing. }\end{array}$ & $\begin{array}{l}\text { Rolling on a flat mat, climbing on a high } \\
\text { mat, walking during gymnastics, single leg } \\
\text { on rope ladder, double leg ricochet. }\end{array}$ & $\begin{array}{l}\text { To be able to roll, climb, walk in balance, } \\
\text { bounce in a balanced and smooth manner. }\end{array}$ \\
\hline $\begin{array}{l}\text { Climbing, gripping and } \\
\text { swinging }\end{array}$ & $\begin{array}{l}\text { Climbing the bars, holding on to the } \\
\text { pull-ups and swinging in the ring. }\end{array}$ & $\begin{array}{l}\text { Climb the gymnastic bars, stand holding on } \\
\text { to the pull-up bar and swing in the ring. }\end{array}$ \\
\hline
\end{tabular}




\begin{tabular}{|c|c|c|}
\hline $\begin{array}{l}\text { Dribbling, shooting, passing } \\
\text { in basketball. }\end{array}$ & $\begin{array}{l}\text { Working with techniques specific to the } \\
\text { sport branch. }\end{array}$ & $\begin{array}{l}\text { To be able to perform the skills specific to } \\
\text { sports branches in accordance with their } \\
\text { technique. }\end{array}$ \\
\hline $\begin{array}{l}\text { Dribbling, shooting, passing } \\
\text { in football. }\end{array}$ & $\begin{array}{l}\text { Working with techniques specific to the } \\
\text { sport branch. }\end{array}$ & $\begin{array}{l}\text { To be able to perform the skills specific to } \\
\text { sports branches in accordance with their } \\
\text { technique. }\end{array}$ \\
\hline Bouncing, jumping & $\begin{array}{l}\text { To jump out of the gym vault, to jump } \\
\text { down from the gym vault. }\end{array}$ & $\begin{array}{l}\text { Jumping out of the gymnastics vault, } \\
\text { jumping down from the gymnastics vault. }\end{array}$ \\
\hline $\begin{array}{l}\text { Dribbling, shooting, passing } \\
\text { in basketball. }\end{array}$ & $\begin{array}{l}\text { Working with techniques specific to the } \\
\text { sport branch. }\end{array}$ & $\begin{array}{l}\text { To be able to perform the skills specific to } \\
\text { sports branches in accordance with their } \\
\text { technique. }\end{array}$ \\
\hline $\begin{array}{l}\text { Dribbling, shooting, passing } \\
\text { in football. }\end{array}$ & $\begin{array}{l}\text { Working with techniques specific to the } \\
\text { sport branch. }\end{array}$ & $\begin{array}{l}\text { To be able to perform the skills specific to } \\
\text { sports branches in accordance with their } \\
\text { technique. }\end{array}$ \\
\hline Bouncing, jumping & $\begin{array}{l}\text { To jump out of the gym vault, to jump } \\
\text { down from the gym vault. }\end{array}$ & $\begin{array}{l}\text { Jumping out of the gymnastics vault, } \\
\text { jumping down from the gymnastics vault. }\end{array}$ \\
\hline $\begin{array}{l}\text { Sporty educational games, } \\
\text { Group work. }\end{array}$ & $\begin{array}{l}\text { Working with techniques specific to the } \\
\text { sport branch. }\end{array}$ & $\begin{array}{l}\text { To be able to hold, control and throw balls } \\
\text { of different sizes and weights with both } \\
\text { hands and feet. }\end{array}$ \\
\hline $\begin{array}{l}\text { Sporty educational games, } \\
\text { Group work. }\end{array}$ & $\begin{array}{l}\text { Working with techniques specific to the } \\
\text { sport branch. }\end{array}$ & $\begin{array}{l}\text { To be able to roll, climb, balance and } \\
\text { bounce with balance and smoothness. }\end{array}$ \\
\hline Rhythmic m & $\begin{array}{l}\text { Making rhythmic movements accompanied } \\
\text { by music, going up and down the step } \\
\text { board. }\end{array}$ & $\begin{array}{l}\text { To be able to make rhythmic movements as } \\
\text { a group with music, to go up and down the } \\
\text { step board as a group. }\end{array}$ \\
\hline $\begin{array}{l}\text { Sporty educational games, } \\
\text { Group work. }\end{array}$ & $\begin{array}{l}\text { Studies with educational games specific to } \\
\text { sports branches. }\end{array}$ & $\begin{array}{l}\text { To be able to perform the skills specific to } \\
\text { sports branches in accordance with their } \\
\text { technique. }\end{array}$ \\
\hline $\begin{array}{l}\text { Sporty educational games, } \\
\text { Group work. }\end{array}$ & $\begin{array}{l}\text { Studies with educational games specific to } \\
\text { sports branches. }\end{array}$ & $\begin{array}{l}\text { To be able to play games in pairs and as a } \\
\text { group, to obey the rules. }\end{array}$ \\
\hline Rhythmic mo & $\begin{array}{l}\text { Making rhythmic movements accompanied } \\
\text { by music, going up and down the step } \\
\text { board. }\end{array}$ & $\begin{array}{l}\text { To be able to make rhythmic movements as } \\
\text { a group with music, to go up and down the } \\
\text { step board as a group. }\end{array}$ \\
\hline $\begin{array}{l}\text { Sporty educational games, } \\
\text { Group work. }\end{array}$ & $\begin{array}{l}\text { Studies with educational games specific to } \\
\text { sports branches. }\end{array}$ & $\begin{array}{l}\text { e to play games in pairs and as a } \\
\text { obey the rules. }\end{array}$ \\
\hline $\begin{array}{l}\text { Sporty educational games, } \\
\text { Group work. }\end{array}$ & $\begin{array}{l}\text { Studies with educational games specific to } \\
\text { sports branches. }\end{array}$ & $\begin{array}{l}\text { To be able to play games in pairs and as a } \\
\text { group, to obey the rules. }\end{array}$ \\
\hline Skill coordination tests. & Practice skill coordination tests in the gym. & $\begin{array}{l}\text { To be able to apply skill coordination tests } \\
\text { that require strength, quickness and skill in } \\
\text { the gymnasium. }\end{array}$ \\
\hline $\begin{array}{l}\text { Sporty educational games, } \\
\text { Group work. }\end{array}$ & $\begin{array}{l}\text { Studies with educational games specific to } \\
\text { sports branches. }\end{array}$ & $\begin{array}{l}\text { To be able to play games in pairs and as a } \\
\text { group, to obey the rules. }\end{array}$ \\
\hline $\begin{array}{l}\text { Sporty educational games, } \\
\text { Group work. }\end{array}$ & $\begin{array}{l}\text { Studies with educational games specific to } \\
\text { sports branches. }\end{array}$ & $\begin{array}{l}\text { To be able to play games in pairs and as a } \\
\text { group, to obey the rules. }\end{array}$ \\
\hline Skill coordination tests. & Practice skill coordination tests in the gym. & $\begin{array}{l}\text { To be able to apply skill coordination tests } \\
\text { that require strength, quickness and skill in } \\
\text { the gymnasium. }\end{array}$ \\
\hline
\end{tabular}

When Table 2 is examined, the contents, objectives and targets applied in the movement education program are indicated. 


\section{Macrothink}

\section{Discussion}

\subsection{Before Applications}

The project started with the trainers training seminar of the Special Olympics Association. As of this date, a road map was determined by holding a meeting with our faculty members who deal with children with special needs at Atatürk University Faculty of Sports Sciences. First of all, interviews were held with special education schools and partner schools. As partners, meetings were held with Atatürk University, private foundation schools administrators and parents. We got a positive response from parents. We gave information about the compliance of the necessary safety and health conditions. It was stated that the application materials needed would be provided by the private athletes' association.

In the second stage, the parents of the students attending the special education school were interviewed. They expressed their satisfaction that the parents had information about previous studies. It was stated that transportation and sportswear will be covered by the private athletes' association. We determined the working days and hours by having a general meeting with the families. Considering the special programs of the children participating in the project, we planned to work between 15:00 and 16:00 on Saturday and Sunday, which is suitable for all. Regarding the volunteer students, we formed a group of 20-25 students among the students who take physical education and therapeutic recreation for the disabled in our faculty. We tried to provide motivation by meeting with the students twice by giving information about the project.

\subsection{In Implementation Phase}

On Saturdays and Sundays, we came to the halls one hour before working with volunteer students and faculty members and prepared the study plan for that day. We organized the stations by taking the necessary materials from the sports room and carrying them to the exercise room. When all the little athletes arrived, we started working with general games and warm-ups. Then we assigned 1 or 2 volunteer students for each of our little athletes. During the study, we made the necessary warnings by checking the groups with our faculty members. After each exercise, we rewarded the children themselves, their volunteer coaches and their parents by applauding. The award ceremony held after the last work was also covered in the local press. At the award ceremony, we gave medals to each child by highlighting one of their characteristics (fastest running, best throwing, collecting the most balls, most ambitious employee, etc.).

\subsection{A Few Remarkable Stories During the Project Implementation Process}

One of our partner students came to the first study with her sister and participated in the study without leaving her sister. From the third study, it was observed that she created a confidence by participating in self-studies.

Again, one of our partner students is inside the circle and $10 \mathrm{~cm}$. While he could not jump with help on the step board at a height, he was born to the last studies by himself $10-15 \mathrm{~cm}$. Confidence in jumping to heights was formed. 
While one of our special education students was just sitting on the ground and playing with yellow balls in the first days, towards the final studies, she started running with the volunteer student and filling all the balls in the bucket.

Again, one of our special education students started to work with other volunteer students towards the end, while she was working only with her aunt, who was a volunteer.

During the project phase, it was observed that the parents were constantly smiling, taking pictures and videos, and expressing their satisfaction after the work.

\section{Conclusion}

As a result, it has been seen that recreational activities, which bring together individuals with special needs and peers, have a positive effect on children's development and social interaction. Ogelman et al. (2019) a significant result of the such studies revealed that even the family involvement alone could lead to an increase in social and communication skills of the children. The program manual can be distributed to the teachers working in disadvantageous regions and their in-service training activities can be planned for the purpose of preventing the social-emotional incompetence of the children. In addition applied courses on methods for coping with the behavioral problems should be provided to the candidate teachers at universities. It should not be forgotten that the participation of families with children who are expected to develop in the studies carried out is of great importance. In the Social Skills Education program applied by Göktaş (2015) to improve the social skills of 4-5 year-old children, the greatest improvement was observed in the application of family involvement program; on the other hand, the second major improvement was determined in the children for whom only the program was applied, and the third one was observed in the group where only family involvement was applied.

\section{References}

Arslan, E., Erbay, F., \& Saygın, Y. (2010). Yaratıcı drama ile bütünleştirilmiş iletişim becerileri eğitiminin çocuk gelişimi ve eğitimi bölümü öğrencilerinin iletişim becerilerine etkisinin incelenmesi. Selçuk Üniversitesi Sosyal Bilimler Enstitüsü Dergisi, 23, 1-8.

Dönmez, B., Avcı, N., \& Aslan, N. (1997). Entegrasyona Katılan Ve Katılmayan Bireylerin Entegrasyona İlişkin Görüşlerinin İncelenmesi. 7 Özel Eğitim Günleri, Eskişehir.

Gampel, H. D, Galtlieb, J., \& Harrison, H. R. (1974). Comparison of classroom behavior of specialclass EMR, Integrated EMR, Low IQ and Nonretarded Children. American Journal of Mental Deficiency, 79(I), 16-21.

Göktaş, İ. (2015). Aile katılımı ve sosyal beceri eğitimi programlarının tek başına ve birlikte 4-5 yaş çocuklarının sosyal becerileri ve anne-çocuk ilişkileri üzerindeki etkisinin incelenmesi (Yayımlanmamış yüksek lisans tezi, Pamukkale Üniversitesi, Denizli).

Burgoon, J. K., Berger, C. R., \& Waldron, V. R. (2000), Mindfulness and Interpersonal Communication. Journal of Social Issues, 56, 105-127. https://doi.org/10.1111/0022-4537. 00154 


\section{Macrothink}

Kırcaali-İftar, G. (1992). Türkiye ve Amerika Birleşik Devletleri'nde Anasınıfına Devam Eden Çocukların Oyun Davranışlarının İncelenmesi. Kırıkkale Üniversitesi Sosyal Bilimler Dergisi, 1(1), 279-298.

Kırcaali-iftar, G. (1992). Özel Egitimde Kaynaştıma. Egitim ve Bilim, 16(86), 45-50.

Leseman, P. P., Rollenberg, L., \& Rispens, J. (2001). Playing and working in kindergarten: cognitive co-construction in two educational situations. Early Childhood Research Quarterly, 16(3), 363-384. https://doi.org/10.1016/S0885-2006(01)00103-X

MEB (Milli Eğitim Bakanlığı). (2010). Playing and working in kindergarten: Cognitive co-construction in different educational situations. Early Childhood Research Quarterly, 16(3), 363-384. https://doi.org/10.1016/S0885-2006(01)00103-X

Metin, N. (1992). Okul Öncesi Dönemde Özürlü Çocuklar İçin Kaynaştırma Programları. Özel Ĕ̈itim Dergisi, 1(2), 32-36. https://doi.org/10.1501/Ozlegt_0000000118

MEB (Milli Eğitim Bakanlığı). (2000). Özel Ĕgitim Hizmetleri Yönetmeliği.

Ogelman, H. G., Sarikaya, H. E., Güngör, H., \& Körükçü, Ö. (2019). Examining the Effect of Social-Emotional Prevention Program on Social and Communication Skills of Disadvantaged Preschool Children. International Journal of Academic Research in Education, 4(1-2), 27-40. https://doi.org/10.17985/ijare.525173

Sucuoğlu, B. (2006). Etkili Kaynaştırma Uygulamaları. Ekinoks Yayınevi, Ankara.

Zirpoli, T., \& Melloy, K. (1997). Behavior management: Applications for teachers and partners (2nd ed., p. 106). Upper Saddle River, NJ: Prentice Hall.

\section{Copyright Disclaimer}

Copyright for this article is retained by the author(s), with first publication rights granted to the journal.

This is an open-access article distributed under the terms and conditions of the Creative Commons Attribution license (http://creativecommons.org/licenses/by/3.0/). 